\title{
Interactive Response Technology Validation Certificate
}

National Cancer Institute

\section{Source}

National Cancer Institute. Interactive Response Technology Validation Certificate. NCI

Thesaurus. Code C115471.

Official records that confirm the validity of the interactive response technology. 